\title{
EDITORIAL
}

\section{Asthma, rhinitis and air pollution: is traffic to blame?}

\author{
B. Brunekreef*, J. Sunyer"
}

This issue of the European Respiratory Journal contains two papers that contribute to a growing body of evidence incriminating traffic fumes in respiratory disease. NICOLAI et al. [1] report a cross-sectional study that finds significant associations between traffic counts and exposure to trafficrelated air pollution on the one hand and current asthma, wheeze and cough on the other. In a sub-group of children exposed to environmental tobacco smoke, traffic counts are also related to allergic sensitisation. LEE et al. [2] report a large questionnaire survey from Taiwan, in which a composite measure of exposure to traffic-related air pollution is found to be associated with physician-diagnosed allergic rhinitis. A parallel analysis reported previously [3] found a similar association between traffic-related air pollution and physiciandiagnosed as well as questionnaire-reported asthma.

How do these studies relate to earlier work on air pollution and childhood respiratory illness? How do they relate to earlier work on traffic-related pollution?

Large-scale, cross-sectional studies on air pollution and respiratory outcomes in children have been reported from the USA [4], Switzerland [5], Canada [6] and Austria [7]. The US and Swiss studies found associations between some air pollutants (especially fine particles) and cough and bronchitis symptoms, the Canadian study found no relationships and the Austrian study documented associations between nitrogen dioxide $\left(\mathrm{NO}_{2}\right.$; described as a marker for traffic-related air pollution) and asthma, wheeze and cough. East/West comparisons have generally highlighted high bronchitis and cough prevalence in the East, which were ascribed to "classical" pollution, consisting of sulphur dioxide $\left(\mathrm{SO}_{2}\right)$ and particles [8], with higher rhinitis in the West. A recent study from California, USA, found an association between wheeze prevalence and the air pollution components, acid and $\mathrm{NO}_{2}$. Taken together, these findings suggest that society is witnessing a transition from classical pollution, dominated by $\mathrm{SO}_{2}$ and particles generated by coal and oil combustion, with the effects primarily on cough and bronchitis, to pollution mixtures dominated by traffic exhausts represented by $\mathrm{NO}_{2}$, with effects on wheeze and perhaps asthma prevalence.

It is important to look at what precisely is the definition of asthma in some of these studies. The paper by NICOLAI et al. [1] defines asthma as a report by parents that a doctor has diagnosed asthma at least once or that a doctor has diagnosed asthmatic, spastic or obstructive bronchitis more than once. This definition therefore includes, to some extent, symptoms that may be bronchitic rather than asthmatic. "Current asthma" is then defined as a combination of asthma and wheeze symptoms occurring in the past year. The study

*Institute for Risk Assessment Sciences, Utrecht University, the Netherlands and ${ }^{\#}$ Institut Municipal d'Investigatio Medica, Barcelona, Spain.

Correspondence: B. Brunekreef, Institute for Risk Assessment Sciences, Utrecht University, PO Box 80176, 3508 TD, Utrecht, the Netherlands. Fax: 31 302535077. E-mail: b.brunekreef@iras.uu.nl performed by GUO et al. [3] in Taiwan used two definitions: the first was the parental report of a doctor's diagnosis of asthma at any point throughout life; the second reported dyspnoea and nocturnal dyspnoea associated with wheezing and/or attacks of dyspnoea with wheezing and/or physiciandiagnosed asthma. Although both studies used the International Study of Asthma and Allergies in Childhood (ISAAC) questionnaire to collect symptom and diagnosis data, the construction of the asthma variables used in the analysis was different, so that a direct comparison becomes difficult. The study by Nicolai et al. [1] is one of the few in the literature that has investigated bronchial hyperresponsiveness in relation to air pollution, only to find that there was no association. Another ISAAC study, conducted in France, found that "wheeze in the last 12 months" and "asthma ever" were related to ozone but not $\mathrm{SO}_{2}$ and $\mathrm{NO}_{2}$ in a simple regression analysis. However, all associations disappeared after adjustment for a family history of asthma, early childhood respiratory disease and socioeconomical status [9]. Surely, the worldwide variation in the prevalence of asthma is so large that it seems unlikely that traffic-related air pollution is a major determinant of this variation [10]. Nevertheless, it seems the respiratory arena is gradually seeing more data suggesting that asthma prevalence may, to some extent, be determined by air pollution, especially traffic-related air pollution, and that it may not just be a factor triggering attacks in patients with developed asthma. A recent longitudinal report suggesting that children exercising in a high ozone area developed more asthma is another piece of evidence that makes the respiratory field more hesitant to say that air pollution does not induce new asthma cases [11].

The new studies from Taiwan add further observations on air pollution and allergic rhinitis to previous findings. Surprisingly few air pollution studies have addressed allergic rhinitis as an endpoint. A report from Leipzig, Germany [12], investigated upper respiratory symptoms, including runny nose, cough and hoarseness and found these to be related to high $\mathrm{SO}_{2}$ levels and intermediate particulate matter (PM) and $\mathrm{NO}_{x}\left(\mathrm{NO}+\mathrm{NO}_{2}\right)$ levels. The French ISAAC study found no relationship whatsoever between air pollution and allergic rhinitis [9]. Other reports show that rhinoconjunctivitis symptoms are increased with higher concentrations of ozone and $\mathrm{NO}_{2}$, and, to a lesser extent, PM10 [13], and that daily consultations, with a general practitioner for allergic rhinitis, increases with ozone and $\mathrm{SO}_{2}$ [14]. It is clear that more studies are needed on air pollution and allergic rhinitis.

How could traffic-related air pollution influence asthma and allergic rhinitis? Experimental evidence obtained in studies on human volunteers, animals and in vitro test systems, suggest that diesel exhaust particles have the capability to: 1) enhance immunological responses to allergens; and 2) elicit inflammatory reactions in the airways at relatively low concentrations and short exposure durations [15-22]. The promoting role of $\mathrm{NO}_{2}$ in the allergen response has also been reported, but only in a few studies on asthmatics [23]. It is 
difficult, in observational studies, to separate effects of pollutants from different types of vehicles. Questionnaire studies do suggest that perhaps heavy traffic powered by diesel engines is more harmful when compared with light traffic powered by gasoline engines [24-26]. Work undertaken in the Netherlands that was able to use objective traffic counts as exposure metrics suggested the same [27-29].

The use of geographical information systems to obtain more accurate measures of exposure to traffic-related air pollution, as in the study by NiCOLAI et al. [1], has increased. The power of such systems was well illustrated by two subsequent analyses from Nottingham, UK. The first found no relationship between traffic activity and wheeze in school children when analysing traffic activity in the living area in tertiles [30]. When the same material was analysed for children living within short distances of major roads, a clear relationship with wheeze was observed [31]. Similarly, the use of data on home location with respect to roads and traffic density on those roads resulted in observations of significant relationship with: 1) respiratory hospital admission rates in Toronto, Canada [32]; 2) rates of childhood asthma hospitalisation in New York, USA [33]; and 3) childhood asthma medical care visits in San Diego County, USA [34]. These and other studies suggest that improvement of accuracy and precision of exposure classification helps to detect associations between adverse respiratory outcomes in children and, in a few studies, adults.

The Taiwan studies [2, 3] have used factor analysis to develop one indicator variable to characterise traffic-related air pollution. Not surprisingly, the primary pollutants, carbon monoxide and $\mathrm{NO}_{\mathrm{x}}$, contribute strongly and positively to this factor. However, at the same time, ozone has a negative loading, most likely related to the well-known fact that ozone concentrations are low in areas where primary emission concentrations are high. The interpretation then becomes complicated. Surely the associations found should not be interpreted as showing a protective effect of ozone but rather as suggesting an important role for primary combustion products from traffic. There are only a few other studies that have used pollution factors, rather than single components, as exposure variables. In one example, factor analysis was used to estimate the contribution of various sources to ambient PM2.5 concentrations [35]. PM2.5 from motor vehicles and coal combustion, but not from crustal sources, was found to be related to daily mortality in that particular case.

The two studies published in this issue of the European Respiratory Journal not only contribute to the present knowledge of the effects of traffic-related pollution, but also show new direction for exposure assessment methods that may help to improve traffic studies in the future.

\section{References}

1. Nicolai T, Carr D, Weiland SK, et al. Urban traffic and pollutant exposure related to respiratory outcomes and atopy in a large sample of children. Eur Respir $J$ 2003; 21 : 956-963.

2. Lee Y-L, Shaw C-K, Su H-J, et al. Climate, traffic-related air pollutants, and allergic rhinitis prevalence in middle-school children in Taiwan. Eur Respir $J$ 2003; 21: 964-970.

3. Guo YL, Lin YC, Sung FC, et al. Climate, traffic-related air pollutants, and asthma prevalence in middle-school children in Taiwan. Environ Health Perspect 1999; 107: 1001-1006.

4. Dockery DW, Cunningham J, Damokosh AI, et al. Health effects of acid aerosols on North American children: respiratory symptoms. Environ Health Perspect 1996; 104: 500-505.

5. Braun-Fahrlander C, Vuille JC, Sennhauser FH, et al.
Respiratory health and long-term exposure to air pollutants in Swiss schoolchildren. SCARPOL Team. Swiss Study on Childhood Allergy and Respiratory Symptoms with Respect to Air Pollution, Climate and Pollen. Am J Respir Crit Care Med 1997; 155: 1042-1049.

6. Stern B, Jones L, Raizenne M, Burnett R, Meranger JC, Franklin CA. Respiratory health effects associated with ambient sulfates and ozone in two rural Canadian communities. Environ Res 1989; 49: 20-39.

7. Studnicka M, Hackl E, Pischinger J, et al. Traffic-related $\mathrm{NO}_{2}$ and the prevalence of asthma and respiratory symptoms in seven year olds. Eur Respir J 1997; 10: 2275-2278.

8. von Mutius E, Fritzsch C, Weiland SK, Roll G, Magnussen H. Prevalence of asthma and allergic disorders among children in united Germany: a descriptive comparison. BMJ 1992; 305: 1395-1399.

9. Ramadour M, Burel C, Lanteaume A, et al. Prevalence of asthma and rhinitis in relation to long-term exposure to gaseous air pollutants. Allergy 2000; 55: 1163-1169.

10. Worldwide variation in prevalence of symptoms of asthma, allergic rhinoconjunctivitis, and atopic eczema: ISAAC. The International Study of Asthma and Allergies in Childhood (ISAAC) Steering Committee. Lancet 1998; 351: 1225-1232.

11. McConnell R, Berhane $\mathrm{K}$, Gilliland $\mathrm{F}$, et al. Asthma in exercising children exposed to ozone: a cohort study. Lancet 2002; 359: 386-391.

12. von Mutius E, Sherrill DL, Fritzsch C, Martinez FD, Lebowitz MD. Air pollution and upper respiratory symptoms in children from East Germany. Eur Respir J 1995; 8: $723-728$

13. Riediker M, Monn C, Koller T, Stahel WA, Wuthrich B. Air pollutants enhance rhinoconjunctivitis symptoms in pollenallergic individuals. Ann Allergy Asthma Immunol 2001; 87: 311-318.

14. Hajat S, Haines A, Atkinson RW, Bremner SA, Anderson HR, Emberlin J. Association between air pollution and daily consultations with general practitioners for allergic rhinitis in London, United Kingdom. Am J Epidemiol 2001; 153: 704 714.

15. Rudell B, Blomberg A, Helleday R, et al. Bronchoalveolar inflammation after exposure to diesel exhaust: comparison between unfiltered and particle trap filtered exhaust. Occup Environ Med 1999; 56: 527-534.

16. Rudell B, Ledin MC, Hammarstrom U, Stjernberg N, Lundback B, Sandstrom T. Effects on symptoms and lung function in humans experimentally exposed to diesel exhaust. Occup Environ Med 1996; 53: 658-662.

17. Muranaka M, Suzuki S, Koizumi K, et al. Adjuvant activity of diesel-exhaust particulates for the production of $\mathrm{IgE}$ antibody in mice. J Allergy Clin Immunol 1986; 77: 616623.

18. Nordenhall C, Pourazar J, Ledin MC, Levin JO, Sandstrom T, Adelroth E. Diesel exhaust enhances airway responsiveness in asthmatic subjects. Eur Respir J 2001; 17: 909-915.

19. Diaz-Sanchez D. The role of diesel exhaust particles and their associated polyaromatic hydrocarbons in the induction of allergic airway disease. Allergy 1997; 52: Suppl. 38, 52-58.

20. Miyabara Y, Takano H, Ichinose T, Lim HB, Sagai M. Diesel exhaust enhances allergic airway inflammation and hyperresponsiveness in mice. Am J Respir Crit Care Med 1998; 157: 1138-1144.

21. Diaz-Sanchez D, Penichet-Garcia M, Saxon A. Diesel exhaust particles directly induce activated mast cells to degranulate and increase histamine levels and symptom severity. J Allergy Clin Immunol 2000; 106: 1140-1146.

22. van Zijverden M, Granum B. Adjuvant activity of particulate pollutants in different mouse models. Toxicology 2000; 152: 69-77.

23. Strand V, Rak S, Svartengren M, Bylin G. Nitrogen dioxide exposure enhances asthmatic reaction to inhaled allergen in subjects with asthma. Am J Respir Crit Care Med 1997; 155: 881-887. 
24. Duhme H, Weiland SK, Keil U, et al. The association between self-reported symptoms of asthma and allergic rhinitis and self-reported traffic density on street of residence in adolescents. Epidemiology 1996; 7: 578-582.

25. Weiland SK, Mundt KA, Ruckmann A, Keil U. Selfreported wheezing and allergic rhinitis in children and traffic density on street of residence. Ann Epidemiol 1994; 4: 243-247.

26. Ciccone G, Forastiere F, Agabiti N, et al. Road traffic and adverse respiratory effects in children. SIDRIA Collaborative Group. Occup Environ Med 1998; 55: 771-778.

27. Brunekreef B, Janssen NA, de Hartog J, Harssema H, Knape M, van Vliet P. Air pollution from truck traffic and lung function in children living near motorways. Epidemiology 1997; 8: 298-303.

28. van Vliet P, Knape M, de Hartog J, Janssen N, Harssema H, Brunekreef B. Motor vehicle exhaust and chronic respiratory symptoms in children living near freeways. Environ Res 1997; 74: $122-132$.

29. Roorda-Knape MC, Janssen NAH, de Hartog J-J, van Vliet PHN, Harssema H, Brunekreef B. Air pollution from traffic in city districts near major motorways. Atmos Environ 1998; 32: 1921-1930.
30. Venn A, Lewis S, Cooper M, et al. Local road traffic activity and the prevalence, severity, and persistence of wheeze in school children: combined cross sectional and longitudinal study. Occup Environ Med 2000; 57: 152-158.

31. Venn AJ, Lewis SA, Cooper M, Hubbard R, Britton J. Living near a main road and the risk of wheezing illness in children. Am J Respir Crit Care Med 2001; 164: 2177-2180.

32. Buckeridge DL, Glazier R, Harvey BJ, Escobar M, Amrhein C, Frank J. Effect of motor vehicle emissions on respiratory health in an urban area. Environ Health Perspect 2002; 110: 293-300.

33. Lin S, Munsie JP, Hwang SA, Fitzgerald E, Cayo MR. Childhood asthma hospitalization and residential exposure to state route traffic. Environ Res 2002; 88: 73-81.

34. English P, Neutra R, Scalf R, Sullivan M, Waller L, Zhu L. Examining associations between childhood asthma and traffic flow using a geographic information system. Environ Health Perspect 1999; 107: 761-767.

35. Laden F, Neas LM, Dockery DW, Schwartz J. Association of fine particulate matter from different sources with daily mortality in six U.S. cities. Environ Health Perspect 2000; 108: 941-947. 